\title{
SISTEM PENGENALAN AYAT AL-QURAN SURAH AL-QALAM MENGGUNAKAN METODE TRANSFORMASI LAPLACE
}

\author{
Reza Yuzanna ${ }^{1}$ Mutammimul Ula ${ }^{2}$ Risawandi ${ }^{3}$ \\ Program Studi Teknik Informatika \\ Universitas Malikussaleh \\ Jl. Kampus Unimal Bukit Indah Blang Pulo \\ rezameutuah@gmail.com ${ }^{1}$
}

\begin{abstract}
Abstrak
Abstrak - Al-Qur'an adalah kitab suci umat islam yang berisi firman-firman Allah SWT, yang diwahyukan kepada Nabi Muhammad SAW sebagai pedoman bagi umat manusia dalam mencapai kebahagiaan hidup di dunia dan di akhirat. Penelitian ini membahas bagaimana bunyi suara ayat Al-Qur'an pada Surah Al-Qalam yang akan ditransformasikan dari domain sinyal suara analog menjadi domain sinyal digital dengan melakukan proses pengolahan persamaan gelombang secara diferensial dengan menerapkan metode Transformasi Lapalce. Transformasi Laplace berperan untuk menyederhanakan permasalahan dalam suatu sistem yang mengandung masukan dan keluaran, Hasil penelitian menunjukkan bahwa Sistem Pengenalan Ayat Al-Qur'an Surah Al-Qalam menggunakan metode Transformasi Laplace ini bekerja sangat baik dengan nilai keakuratan mencapai $82 \%$.
\end{abstract}

Kata Kunci : Al-Qur'an, sinyal analog, sinyal digital, Pengenalan Suara, Tranformasi lapalce.

\section{Pendahuluan}

Al-Qur'an adalah kalam Allah yang diturunkan kepada Nabi Muhammad SAW melalui perantara malaikat Jibril dan disampaikan kepada umat manusia untuk dijadikan pedoman dalam kehidupan di dunia ini. Membaca Al-Qur'an merupakan 
ibadah kepada Allah SWT. Al-Qur'an sebagai kitab terakhir dimaksudkan untuk menjadi petunjuk bagi orang-orang yang beriman dan bertaqwa sampai akhir zaman. Di dalamnya terdapat rahmat yang besar dan pelajaran bagi orang-orang yang beriman dan aturan-aturan manusia di dunia dalam hubungan dengan Allah maupun hubungan manusia dengan sesama manusia lainnya dan hubungan manusia dengan alam sekitarnya, Terkadang sebagian orang yang membaca potongan ayat-ayat dalam Al-Qur'an, tidak mengetahui urutan potongan ayat-ayat di bagian surah dalam Al-Qur'an. Hal tersebut membuat penulis tertarik untuk membuat sebuah aplikasi yang dapat mengenali urutan ayat-ayat dan surah dalam Al-Qur'an melalui suara bacaan ayat Al-Qur'an yang kita inputkan.

Berdasarkan uraian permasalahan di atas, maka dari itu penulis mencoba melakukan peneltian tentang Pengenalan Ayat Al-Qur'an Surah Al-Qalam Menggunakan Metode Transformasi Laplace.

\section{Metode Penelitian}

Skema sistem untuk pengenalan ayat Al-Qur'an melalui suara pada Surah Al-Qalam menggunakan metode Transformasi Laplace diilustrasikan pada gambar berikut :

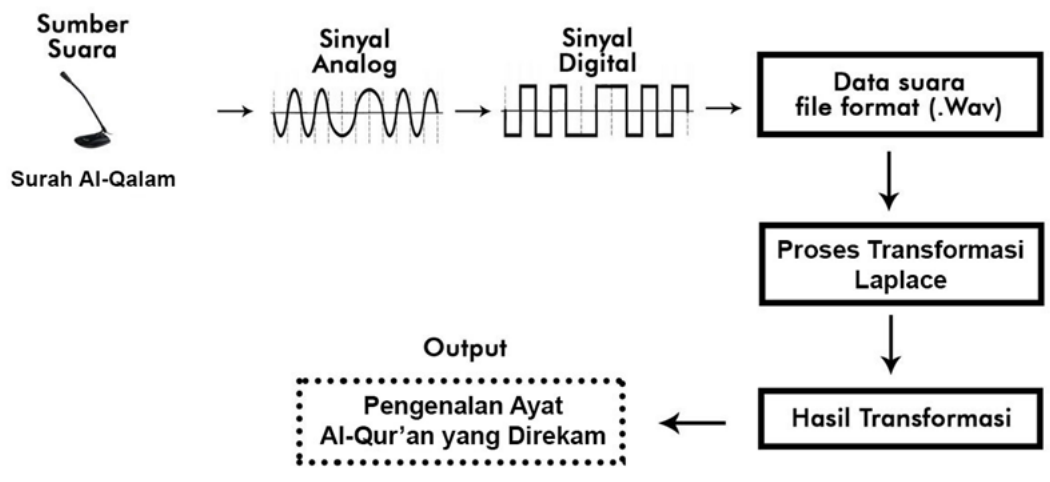

Gambar 1. Skema Sistem 


\section{Hasil dan Pembahasan}

Pengukuran unjuk kerja sistem adalah analisa peneliti untuk mengukur keakuratan kerja sistem pengenalan ayat Al-Qur'an Surah Al-Qalam melalui suara menggunakan Transformasi Laplace ini dengan melakukan pengujian pada sampel suara yang sudah dilakukan pelatihan yaitu Surah Al-Qalam, sehingga dapat diketahui tingkat kebenaran maupun kesalahan deteksi pengenalan suara yang di inputkan. Tabel 4.2 menunjukkan hasil unjuk kerja sistem pengenalan ayat Al-Qur'an Surah Al-Qalam Ayat 1-10 melalui suara menggunakan Transformasi Laplace yang dapat dilihat di bawah ini:

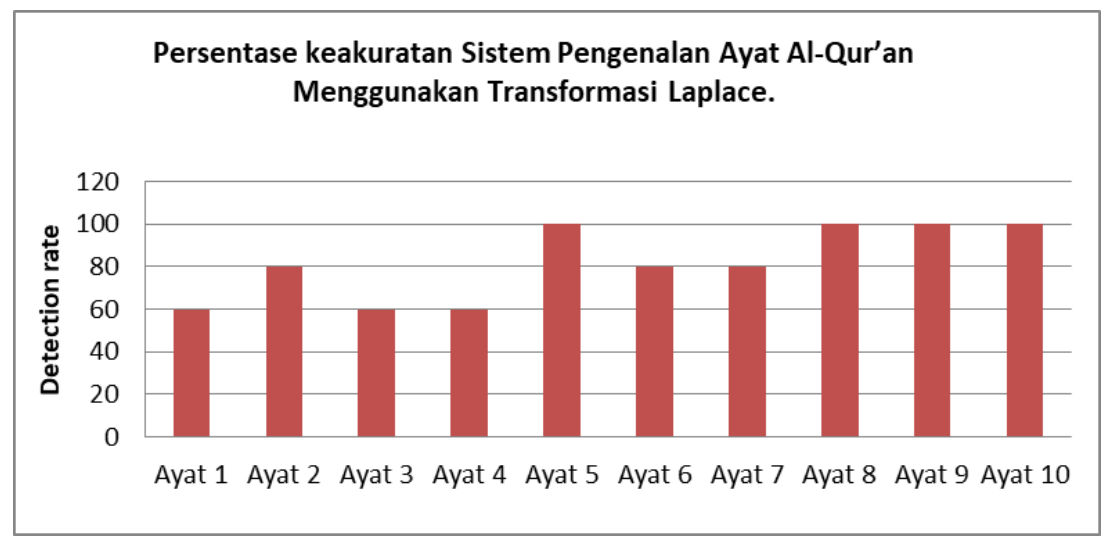

\section{Gambar 2. Grafik persentase pengenalanayat Al-Qur'an}

\section{Kesimpulan}

Research (penelitian) ini menunjukkan bahwa sistem pengenalan ayat Al-Qur'an Surah Al-Qalam dengan menggunakan metode Transformasi Laplace memiliki rata-rata true detection rate adalah $82 \%$ dan false detection rate adalah $18 \%$. Jumlah banyaknya sampel yang dilatih atau diuji mempengaruhi keakuratan sistem pendeteksi.

Dengan menggunakan metode Tranformasi Laplace sistem pengenalan ayat Al-Qur'an lebih mudah terdeteksi jika citra suara 
hasil rekaman tidak pecah dan terdengar lebih jelas. Sistem dibangun dengan mengaplikasikan metode Transformasi Laplace yang dimulai dengan pelatihan suara selanjutnya memasuki proses pengujian suara lalu memasuki tahapan perhitungan menggunakan metode Transformasi Lpalace dan akan didapatkan hasil penelitian. Faktor panjangnya sebuah ayat dalam setiap surah menjadi salah satu kelemahan pada sistem ini, karena sistem pengenalan ayat Al-Qur'an akan bekerja sedikit lebih lambat pada saat merekam suara yang diinputkan dan akan menampilkan hasil setelah suara rekaman tersimpan di data rekaman yang telah dilatih.

\section{Daftar Pustaka}

Al-Qur'an Al-Kareem, Surah Al-Qalam, https://litequran.net/alqalam, (Diakses 8 Mei 2018).

Binyamin Widi Prasetya, dkk, 2008. Identifikasi Suara Pria dan Wanita.https://media.neliti.com/media/publications/6631

1-ID-identifikasi-suara-pria-dan-wanita-berda.pdf, (Diakses 5 Mei 2018)

Fadhilah, Cut. 2015. Tugas Akhir Sistem Pendeteksi Pola Tajwid AlQur'an Hukum Idgham Bighunnah Dan Bila-Ghunnah Menggunakan Metode Nei And Li. Tugas akhir. Prodi Teknik Informatika. Universitas Malikussaleh. Bukit Indah.

Habibullah , Mosleh. 2015. Proses Dan Hasil Penerjemahan Mahasiswa (Studi Kasus Pada Mahasiswa Translation Theory and Practicle Di STAIN pemekasan), Nuansa, Vol.12,1 Januari Juni 2015.

Karmela Saturnina Mega Wea, 2013. Aplikasi Player Untuk Menjalankan File Wave yang Terkompresi dengan Metode Huffman. https://media.neliti.com

/media/publications/68903-ID-none.pdf, (Diakses 8 Mei 2018). 
Kadir, Abdul, 2013. Dasar Pengolahan Citra dengan DELPHI. Yogyakarta : Andi

Muhammad Roihan Daulay, 2014. Studi Pendekatan Al-Qur'an. http:/ / docplayer.info/35916454-Studi-pendekatan-alquranoleh-muhammad-roihan-daulay-abstract.html, (Diakses 5 Mei 2018).

Putra, Darma, 2013. Dasar pengolahan citra digital, Yogyakarta : Andi.

Rasyidin, Abdi, 2012, Sistem Koreksi Cahaya Pada Citra Digital Menggunakan Kamera Metode Konvolusi. Prodi Teknik Informatika Fakultas Teknik Universitas Malikussaleh, Reulet- Aceh Utara.

Rini Mulyani, 2017. Pemetaan dan Analisis Suara Manusia. http://digilib.unila.ac.id/25551/3/SKRIPSI\%20TANPA \%20 BAB\%20PEMBAHASAN.pdf, (Diakses 8 Mei 2018).

Wikipedia, Pengertian Surah Al-Qalam, https://id.wikipedia.org/wiki/Surah_Al-Qalam, (Diakses 5 Mei 2018). 